\title{
Environmental Influence on the Measurement Results when Verifying and Calibrating Radar Level Gauges
}

Jaromír Markovič ${ }^{1}$, Zbyněk Schreier ${ }^{2}$, Stanislav Ďuriš3 ${ }^{3}$ Jana Krivosudská ${ }^{4}$

${ }^{1}$ Slovak Legal Metrology, Hviezdoslavova 31, 97401 Banská Bystrica. Slovak Republic. E-mail: markovic@ slm.sk

${ }^{2}$ Slovak Office of Standards, Metrology and Testing, Štefanovičova 3, 81005 Bratislava 15. Slovak Republic. Email: zbynek.schreier@normoff.gov.sk

${ }^{3}$ Faculty of Mechanical Engineering Slovak University of Technology in Bratislava, Námestie Slobody 17, 81231 Bratislava. Slovak Republic. E-mail: stanislav.duris@ stuba.sk

${ }^{4}$ Faculty of Mechanical Engineering Technical University of Košice, Letná 9, 04200 Košice. Slovak Republic. E-mail: jana.krivosudska@gmail.com

The present paper deals with the metrology, especially with the legal metrology that is responsible for assuring the uniformity and correctness of measurements. In addition to the definition and explanation of the basic terms and principles applied in the metrology, the paper presents especially the results of the scientific and research work in the cross-disciplinary fields of the legal metrology in Slovakia, namely in design and realization of a new measuring system for the verification of the radar level gauges.

Keywords: automatic level gauge, radar level gauge, verification, calibration, electromagnetic waves

\section{References}

[1] BURENIN,P. V., PAKOV, S. V.,SIZIKOV,O. K. (1998). Reducing the measurement errorof pulse-radar level gauges for bulk media. In: Measurement Techniques, 41(6), pp. 533-535, ISSN 05431972.

[2] GU, C., XU, W., WANG, G., INOUE, T., RICE, J. A., RAN, L. and LI, C.(2014). Non contact Large-Scale Displacement Tracking: Doppler Radar for Water Level Gauging. In: IEEE Microwave and Wireless Components Letters, 24(12), pp.899-901.

[3] KIM, S. D., LEE, J. H. (2012). A new transmitted-reference FMCW-UWB radar for gasoline tank level gauge. Proceedings of the 2012 International Conference on Image Processing, Computer Vision, and Pattern Recognition, IPCV 2012. 2, pp. 1171-1174. ISBN: 978-160132225-8.

[4] KIM, S. and NGUYEN, C. (2003). A displacement measurement technique using millimeter-wave interferometry (2003). IEEE Transactions on Microwave Theory and Techniques, 51(6), pp.1724-1728.

[5] LIBERMANN, V. V.(2012). Level measurement using radar level gauges. Automation and RemoteControl, 73(3), pp.566-574, ISSN 00051179.

[6] MICHALECKI, G., (2001). Automatic calibration of gauge blocks measured by optical interferometry. MeasurementScienceReview,1(1), pp.93-96.

[7] MIKUŠ, P., HARŤANSKÝ, R.(2013). The Errors in Radar Level Gauge Calibration. Measurement Science Review MEASUREMENT 2013, Proceedings of the 9th InternationalConference, Smolenice, Slovakia, pp.355-358.

[8] MIKUŠ, P., HARŤANSKÝ, R. ČIČÁKOVÁ, O. (2014). $\square$ iffra tion Probl $\square \mathrm{m}$ in Radar L $\square \square$ Gaug $\square \mathrm{V} \square$ rifi $\square$ ation. In: Universal Journal of Electrical and Electronic Engineering. 2(4), pp. 165-169,

[9] MIKUŠ, P., HAR ŤANSKÝ, R., SMIEŠKO, V. (2016). The proposal of the laboratories for calibration of radar level Gauges. Przeglad Elektrotechniczny, 92(2), pp.72- 74. ISSN 00332097.

[10] MOTZER, J.(2000). PULS RADAR gauge for level measurement and process control. Proceedings of the 1999 IEEE MTT-S International Microwave Symposium; Boston, MA, USA, 3, pp.1563-1566. ISSN 0149645X.

[11] ORÉANS, L., HEIDE, P. (2000). Novel Radar LevelGaugeUsing 24-GHz- Technology. Technisches Messen, 67(5), pp.214-219. ISSN 01718096.

[12] PALENČÁR, R.,HALAJ, M. (1999). Metrologické zabezpečenie systémov riadenia kvality [Metrological assurance of the quality systems management]. 2nd ed. Bratislava: STU Bratislava. ISBN 80-227-1171-3.

[13] PALENČÁR, R., KUREKOVÁ, E., HALAJ, M. (2007). Meranie a metrológia pre manažérov [Measurement and metrology for managers]. Bratislava: STU Bratislava, ISBN 978-80-227-2743-3.

[14] WANG, G., GU, C., RICE, J., INOUE, T., LI, C. (2013). Highly accurate non contact water level monitoring using continuous-wave Doppler radar. WiSNet 2013 - Proceedings: 2013 IEEE Topical Conference on Wireless Sensors and Sensor Networks - 2013 IEEE Radio and Wireless Week, RWW 2013. pp.19-21. 
[15] WEI, M.,XU, K.J., MA, Y.,(2013). An echo signal processing method without reference curve for guided wave radar level gauge. IEEE International Conference on Control and Automation, ICCA. pp.972-977.

[16] ZGODAVOVA, K. (2010). Complexity of entities and its metrological implications, 0365-0367, Annals of DAAAM for 2010 \& Proceedings of the 21st International DAAAM Symposium, ISBN 978-3-901509-73-5, ISSN 1726-9679, pp.0365-0366, B. Katalinic (ed.), Published by DAAAM International, Vienna, Austria 2010.

[17] QINYI MA, QINGCHAO, YANQIU LIU, YAJUN WANG, AND MAOJUN ZHOU: A Method of Carbon Footprint Calculation for the Product Life Cycle. In: Manufacturing Technology, December 2014, Vol. 14, No. 4, ISSN 1213-2489.

[18] MACIK, K., BERAN, T., FINDOVA, S. (2014). The Use of the Matrix Model of Sustainable Development (MSD) in the Production Sector. In: Manufacturing Technology, June 2014, Vol. 14, No. 2, ISSN 1213-2489.

[19] DVOŘÁČKOVÁ, Š. (2016). Gauge Block Calibration by Interferometry. In: Manufacturing Technology, February 2016, Vol. 16, No. 1, ISSN 1213-2489.

[20] JENČURÁKOVÁ, D., PALENČÁR, R. (2016). Optimizing Management of the Measurement System of the Technological Process. In: Manufacturing Technology, 2016, Vol. 16, No. 1, pp. 107-113, ISSN 1213-2489.

Copyright (C) 2016. Published by Manufacturing Technology. All rights reserved. 